\title{
MEROPENEM RESISTANCE IN INTENSIVE CARE UNITS IN UKRAINE
}

\section{OPORNOŚĆ NA LEK MEROPENEM U PACJENTÓW ODDZIAŁÓW INTENSYWNEJ OPIEKI MEDYCZNEJ NA UKRAINIE}

\author{
Oleksandr Oliynyk ${ }^{1(\mathrm{~A}, \mathrm{~B}, \mathrm{C}, \mathrm{D}, \mathrm{E}, \mathrm{F})}$, Anna Ślifirczyk ${ }^{2(\mathrm{~A}, \mathrm{C}, \mathrm{D}, \mathrm{E}, \mathrm{F})}$, Bogdana Pereviznyk $^{3(\mathrm{~B}, \mathrm{E}, \mathrm{F})}$ \\ ${ }^{1}$ Bogomolets National Medical University in Kyiv, Ukraine \\ ${ }^{2}$ Pope John Paul II State School of Higher Education in Biała Podlaska, Poland \\ ${ }^{3}$ I. Horbachevsky Ternopil State Medical University, Ukraine
}

Authors' contribution

Wkład autorów:

A. Study design/planning

zaplanowanie badań

B. Data collection/entry

zebranie danych

C. Data analysis/statistics

dane - analiza i statystyki

D. Data interpretation

interpretacja danych

E. Preparation of manuscript

przygotowanie artykułu

F. Literature analysis/search

wyszukiwanie i analiza literatury

G. Funds collection

zebranie funduszy
Tables: 0

Figures: 2

References: 21

Submitted: 2017 Oct 18

Accepted: 2018 Jan 24

\section{Summary}

The article reviews the issue of antibiotic resistance of microorganisms to meropenem in intensive care units in Ukraine. An increase in meropenem inefficiency against microorganisms in intensive care units has been observed in the last years. The data analysis suggests a significant predominance of gram-negative flora: A. baumannii, P. aeruginosa, K. pneumoniae, E. cloacae, E.coli. On average 30\% of microorganisms are resistant to 5 and more basic antibiotics including meropenem. $40-80 \%$ of the gram-negative flora in intensive care units in Ukraine are resistant to meropenem. This can be attributed to the free sale of antibiotics without prescription, patients' self-treatment, inadequate antibiotic therapy, and failure to comply with sanitary norms on the part of intensive care staff. Microbiological diagnostics of infectious pathogens also needs improvement. Unless proper measures are taken within a few years, meropenem as an antibiotic is likely to disappear in Ukraine.

Keywords: carbapenems, meropenem, antibiotic resistance, intensive care units

Artykuł przedstawia kwestię antybiotykooporności drobnoustrojów na lek meropenem u pacjentów szpitalnych oddziałów intensywnej opieki medycznej na Ukrainie. W ostatnich latach na ukraińskich oddziałach intensywnej opieki medycznej zaobserwowano znaczny wzrost oporności drobnoustrojów na meropenem, a tym samym coraz mniejszą skuteczność tego leku. Przeprowadzona analiza danych wskazuje na znaczną przewage gram-ujemnej flory bakteryjnej oddziałów, w tym szczepów takich jak A. baumannii, P. aeruginosa, K. pneumoniae, E. cloacae czy E.coli. Odsetek szczepów opornych na działanie pięciu lub więcej podstawowych antybiotyków, w tym leku meropenem, wy nosił średio $30 \%$, a odsetek gram-ujemnych szczepów flory bakteryjnej ukraińskich oddziałów intensywnej opieki medycznej opornych na działanie samego meropenemu to aż $40-80 \%$. Głównymi czynnikami powstawania antybiotykooporności w tym przypadku mogą być m.in. sprzedaż antybiotyków bez recepty, samoleczenie, niewłaściwa antybiotykoterapia oraz niespełnianie wymogów sanitarnych przez personel medyczny szpitali. Zdecydowanie należałoby również popracować nad diagnostyką mikrobiologiczną drobnoustrojów patogennych. Jeżeli w ciagu kilku kolejnych lat nie zostaną podjęte odpowiednie działania, meropenem prawdopodobnie zniknie z listy antybiotyków stosowanych na Ukrainie.

Słowa kluczowe: karbapenemy, meropenem, antybiotykooporność, oddziały intensywnej opieki medycznej

\section{Introduction}

The problem of microorganism resistance to carbapenems as stand-by antibiotics is one of the most global issues requiring prompt solution $[1,2]$. This matter is also of much concern in post-Soviet countries, particularly Ukraine. Regrettably, the antibiotic resistance in Ukraine has been found to exceed the normal incidence in European countries and the USA [3]. Further, the prevalence of nosocomial infections in Ukraine (in the last decade 3-4 thousand cases per year; that is $0.08 \%$ [4], points to the lack of systemic solutions that would improve outcomes.

Though urgent and clinically vital, the problem of microorganism resistance to antibiotics, including carbapenems, has not been studied adequately in Ukraine so far. Until now, the incidence of antibiotic resistance of microorganisms taken from the in-patients of surgical hospitals has not been examined systematically. Few 
research works are available concerning the study of antibiotic resistance of clinical strains, mostly found in anesthesiology and intensive care units, which complicates adequate antimicrobial therapy. The available reports, both foreign and national, cannot substitute for thorough research on the spread of microorganism resistance to antibiotics in Ukrainian hospitals at the local, regional and country levels. This is due to significant difference in the use of antibiotics between Ukraine and other countries. With the lack of state-approved analogous research in Ukraine, an analysis of available scientific data on the subject is needed presently. The role of carbapenems in fighting various types of microflora, gram-negative in particular, can hardly be overestimated. Therefore, resistance to carbapenems might be a sign of antibiotic resistance problem on the whole. The authors have done a thorough data search regarding hospital microflora resistance to carbapenems specifically, and now they affirm that no other serious research, beside those mentioned in this paper, has been undertaken in Ukraine. Owing to the lack of research on the subject, the authors understandably come forward with a short analysis of the issue.

\section{Material and methods}

In the ex-SovietUnion, the Ministry of Healthcare issued official orders concerning sanitary and epidemiological standards in medical institutions [5-7], among which one can find the following orders of Ministry of Healthcare of Soviet Union: Order No. 720 of 31.07.1978 and Order No. 380 of 16.04.1975. In Ukraine, There were some attempts to handle the problem of antibiotic resistance in Ukraine in the past, specifically, Order No. 236 of Ministry of Healthcare of 4.04.2012 [8]. However, the data on the microorganism resistance to antibiotics in Ukraine hardly compares with those of the European Union countries as the determination of the sensitivity of microorganisms to antibiotics is implemented according to outdated Order No.535 of Ministry of Healthcare of the Soviet Union of 22.04.1985. The identification of isolated strains of microorganisms is performed according to generally accepted bacteriologic methods, following Bergey's classification (1997). Diagnostic microbiological methods, particularly the disco-diffusion method, are considered reliable in Europe. However, most of our data were obtained by using automated Vitek microbiological analyzers.

Since the primary objective of the paper is microorganism resistance to meropenem, the diagnostics of carbapenemases in Ukraine should be brought to the fore. However, the authors have failed to find any Ukrainian research on carbapenemases.

The early laboratory diagnostics of infectious diseases is essential. It takes at least 3 days to diagnose one or another disease at modern laboratories. At present, Ukraine lacks such laboratories though. Most of the available ones use obsolete equipment and manual methods of pathogen identification. As a result, the diagnostic process takes more than 3 days. Sometimes, the patient dies before the result comes to the doctor. Besides, the Orders listed above had some strict instructions to be followed. Adherence to the those regulations proved to be effective against purulent and septic diseases. Failure to comply with instructions was brought to hospital and department managers' notice by a list which regulated the categories of penalties. Theoretically, these orders are valid today although they are often ignored. It appears to be easier to ignore them and to conceal the existing sanitary and epidemiological situation.

In compliance with the Central Asian and Eastern European Surveillance of Antimicrobial Resistance (CAESAR) network, Ukraine created the All-Ukrainian Association of Infection Control and Antimicrobial Resistance, Ukrainian Committee of Antimicrobial Sensitivity Testing (UCAST) and Ukrainian Committee on Infection Control (UCIC). The formation of these structures was in line with the EU-Ukraine Agreement Association, by the WHO Global Strategy on Containment of Antimicrobial Resistance, the CAESAR Program, and the European Antimicrobial Resistance Surveillance Network EARS-Net. Despite the fact that the abovelisted structures were instituted, the antibiotic resistance in Ukraine remains a pressing problem. The main issue is that antibiotic resistance in intensive care units is higher in Ukraine as compared with surgical and therapeutic departments in other countries [9].

\section{Results and discussion}

The WHO first global report of April 30, 2014 [10] contained a description of antibiotic resistance to 114 antibiotic drugs according to CDC data. The E.coli resistance to meropenem in France and Great Britain was found in less than $0.03 \%$ of cases, in Bulgaria - 0.06\%, in Greece - 0.72\%. The Carbapenem-resistant K.pneumoniae were observed in Austria, Denmark, Germany, Latvia, Lithuania and Sweden in 0\% cases, in Spain and France 0.16-0.17\%, in Poland - 0.72\%. The E.coli resistance to carbapenem in Poland equaled to 1.0\%, and K.pneumoniae resistance did not exceed $2.0 \%$ [11]. 
Currently, gram-negative flora prevails in intensive care units in Ukraine [12]. Any analysis of microflora resistance to meropenem reveals negative dynamics. The research comprising the analysis of 4974 of strains of P. aeruginos was performed in 2009 [13]. The material was obtained from the purulence of in-patients in 97 surgical departments in 25 regions of Ukraine, Kyiv and Sevastopol. The highest resistance to meropenem was detected in Kharkiv (38.6\%), Vinnytsia (32\%) and Volyn (30.9\%) regions, while the lowest one was found in Ivano-Frankivsk (6.1\%) and Khmelnytsk (11.5\%) regions.

According to the data of the major Ukrainian research conducted in the years $2008-2010$ [14], the resistance of E.coli to meropenem in Chernihiv region was $69.8 \pm 7.0 \%$, in Cherkasy region $-23.1 \pm 4.06 \%$, in Sumy region $-23.2 \pm 5.64 \%$, and in Kherson region $-22.3 \pm 3.53 \%$ [15].

Further, the statistical data by the Ukrainian Centre for Control and Monitoring of the Diseases, Ministry of Healthcare of Ukraine, regarding the analysis of multiple resistant strains of microorganisms (insensitive to 5 and more basic antibiotics including carbapenem) [16], showed that the following problems in 2011: multiple resistant A. baumannii was found in $29.1 \%$ of cases, P. aeruginosa $-26.1 \%$, K. pneumoniae $-12.7 \%$, S. haemolyticus $-12.7 \%$, E. cloacae $-7.9 \%$, E. coli $-7.4 \%$, S. aureus $-1.8 \%$, others $-2.3 \%$.

According to the other data from $2012[13,17,18]$, the meropenem effectiveness against P. aeruginosa in the largest hospital of Donetsk was $46.8 \%$.

The research by Kreniov K.Yu. [19] on the microflora dynamics in patients in the intensive care unit was implemented in Khmelnytsk Regional Hospital in the years 2013 - 2015, where 205 isolates were tested. In 2013, 79 isolates were analyzed, and $33.3 \%$ were found to be multiple resistant. $25 \%$ were A. baumannii resistant, $18 \%$ - P. aeruginosa and K. pneumoniae, 13\% - S. epidermidis, E. coli and S. aureus. Gram-negative flora was found in $61 \%$.

In 2015, 64 isolates were tested, 42 (63\%) revealing multiple resistance. The list of multiple resistant was as follows: A. baumannii - 31.3\%, P. aeruginosa - 24.7\%, K. pneumoniae - 9.2\%, S. epidermidis - 6.3\%, E. faecalis $3.2 \%$, S. aureus $-1.6 \%$. Gram-negative flora was observed in $82 \%$.

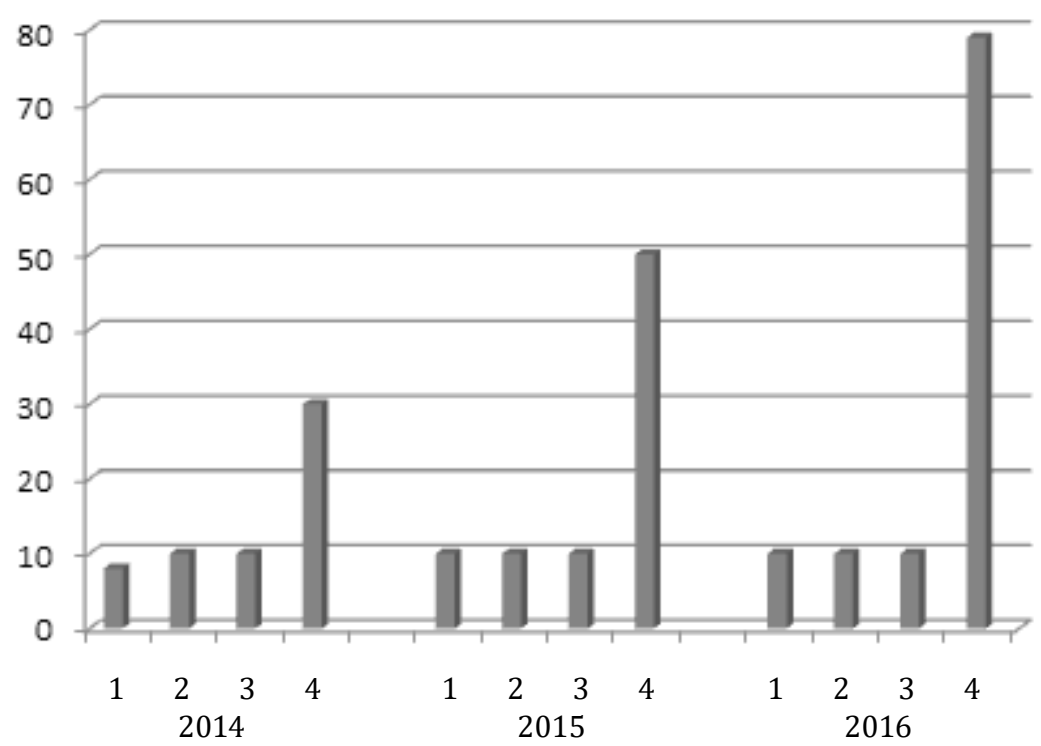

1 - Cefoperazone; 2 - Cefepime; 3 - Imipenem; 4 - Meropenem

Figure 1. Resistance of Klebsiella Pneumoniae to antibiotics in Khmelnitski region Hospital in 2014-2016

In 2014 and 2015, the meropenem resistance among A. baumannii isolates was 52\% and 79\% respectively; P. aeruginosa - 31\% and 71\%; K. pneumoniae - 50\% and 79\%; E. coli - 3\% and 52.2\%. Also, another research conducted in 2015 revealed similar data $(12,20)$. It showed that among those sensitive to meropenem were K. pneumoniae (58.3\%), E. faecium (7.5\%), A. baumannii (19\%), P. aeruginosa $(37.3 \%)$.

The most recent research (2016) by professor Nesterenko O.M. carried out in Kramatorsk revealed $60 \%$ of carbapenem-resistant A.baumanii cases, whereas for K.pneumoniae and Enterobacter spp. the value was $70 \%$ and $67.73 \%$ respectively [21]. 


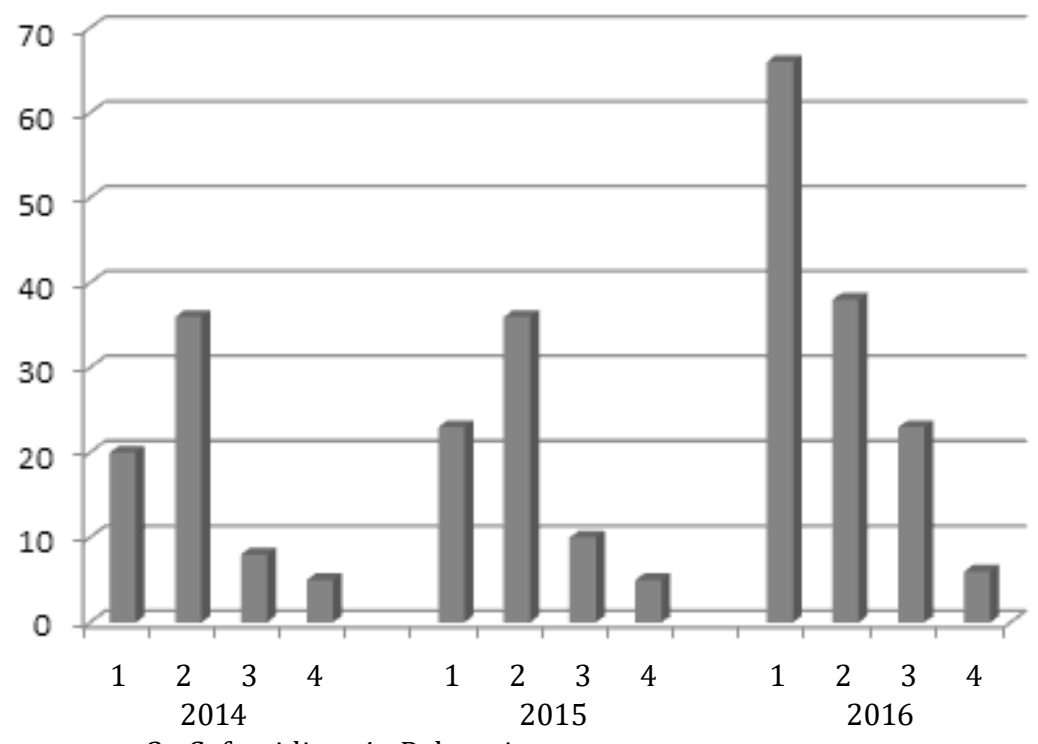

1 - Meropenem; 2- Cefoperazone; 3-Ceftazidine; 4- Polyresistent

Figure 2. Resistance of Pseudomonas aeruginosa to antibiotics in Khmelnitski region Hospital in 2014-2016

Another research study by Hrabák J. et al. 2014 [20] dealt with a Ukrainian patient who was admitted to a Czech hospital due to a severe traumatic brain injury during Euromaidan in 2014. In this particular case, A. baumannii was extracted. A. baumannii synthesized carbapenem-hydrolyzing class of D $\beta$-lactamase. A. baumannii was found to be resistant to ertapenem (MIC $12 \mathrm{mg} / \mathrm{L}$ ), meropenem (MIC $24 \mathrm{mg} / \mathrm{L}$ ) and imipenem (MIC $3 \mathrm{mg} / \mathrm{L}$ ), amikacin, amoxicillin/clavulanic acid, ampicillin cefotaxime, ceftazidime, cefepime, ciprofloxacin, gentamicin, piperacillin/tazobactam, tobramycin and trimethoprim/sulfamethoxazole. However, it was susceptible to aztreonam, colistin and tigecycline. The authors of the paper stress that this particular research concerning to $\beta$-lactamases was unique.

\section{Conclusions}

The primary cause of the antibiotic resistance in Ukraine is the availability of antibiotics in any drugstore. Patients often resort to self-treatment without consulting a doctor. Sometimes, reserve antibiotics are prescribed by doctors for prophylaxis. Another factor increasing the antibiotic resistance in Ukraine is a wide and uncontrolled use of antibiotics as a nutritional supplement in stockbreeding.

Further, basic sanitary standards are not always kept to at intensive care units. The ways of transporting "dirty" and "clean" patients often intersect. According to the Ukrainian standards, 1 nurse should provide care to 4 patients, which also contributes to microflora contamination in the patients' surroundings. The elemental clean-up procedure is often neglected in intensive care units. Microorganisms are known to be carried with disinfectants. It is still common in Ukraine for an assistant nurse to use only one floor cloth for washing the whole the unit floor. The effect is evident. To the authors' view, the fact that antibiotics are available in Ukrainian drugstores without prescription is the major factor of high microorganism resistance to them, whereas in Poland prescribing antibiotics is restricted to certain categories of doctors. A Ukrainian patient can easily do without any prescription as purchasing medicines is not limited in any way. Antibiotic sale regulations which date back to the former USSR have not been cancelled so far. Finally, the lack of any control over drugstores selling antibiotics without prescription makes the situation even more severe.

The mentioned-above Czech research concludes that the problem of antibiotic resistance in Ukraine requires a serious consideration. It should be taken into account that with the Ukrainians crossing the borders of EU countries their microflora can bring about similar health hazards in these territories. 


\section{References:}

1. Baraniak A, Izdebski R, Fiett J. KPC-Like Carbapenemase-Producing Enterobacteriaceae Colonizing Patients in Europe and Israel. Antimicrob Agents Chemother. 2015; 60(3): 1912-7. https://doi.org/10.1128/aac.02756-15

2. Kittinger C, Lipp M, Baumert R. Antibiotic Resistance Patterns of Pseudomonas spp. isolated from the River Danube. Front Microbiol. 2016; 7: 586. https://doi.org/10.3389/fmicb.2016.00586

3. Salmanov AG, Marievsky VF, Boyko VV. Antibiotic resistance in surgery. NTMT; 2012: 10-45.

4. Tolstanov OK, Ponomarenko AM, Salmanov AG. The problem of the antibiotic resistance of pathogens of intra-hospital infections [cited 2018 Jan 24]. Available from: www. zarifacenter.org/articles/article151.pdf

5. Order of the Ministry of Health of the USSR No. 380 on April 16, 1975, "About the state and prospects of development of laboratory clinical diagnostic service in the USSR" [cited 2018 Jan 24]. Available from: http:// www cl.com.ua/normdocs/3003.htm.

6. Order of the Health Ministry of the USSR No. 720 on July 31, 1978 "About Improving of Medical Aid to Patients with Purulent Surgical Diseases and Strengthening Measures to Combat Intrahospital Infection" [cited 2018 Jan 24]. Available from: www.moz.gov.ua/ua/portal/dn_19780731

7. Order of the Health Ministry of the USSR No. 535 on April 22, 1985 "About unification of microbiological (bacteriological) methods of research used in clinical and diagnostic laboratories of medical and prophylactic institutions". [cited 2018 Jan 24]. Available from: www.ask.com

8. Order of the Health Ministry of Ukraine on 04.04.2012 No. 236 "About organization of control and prevention of postoperative purulent inflammatory infections caused by micro-organisms resistant to the action of antimicrobial drugs" [cited 2018 Jan 24]. Available from: zakon.rada.gov.ua/go/z0912-12

9. Krasij NI, Oliynyk OV. Monitoring of antibiotic susceptibility of microbes isolated from the patients of Ternopil University hospital. Człowiek i Zdrowie. 2012; 3: 23-29.

10. WHO's first global report on antibiotic resistance reveals serious, worldwide threat to public health. 2014; [cited 2018 Jan 24]. Available from: http://www.who.int/mediacentre/news/releases/2014/amr-report/en/

11. Narodowy Program Ochrony Antybiotyków [cited 2018 Jan 24]. Available from: http://www.antybiotyki. edu.pl/

12. Glumcher FS. The problem of antibiotic resistance in intensive care department. Materials of VIII BritishUkrainian scientific symposium devoted to the memory of professor I.P. Shlapak, Kyiv, April 20-23, 2016 [cited 2018 Jan 24]. Available from: www.anaesthesiaconference.kiev.ua 20

13. Lazorishinets VV, Marievsky VF, Salmanov AG. Antibiotic resistance of nosocomial strains of Pseudomonas aeruginosa in surgical hospitals of Ukraine in 2009. Kharkiv surgical school. 2010; 6(44): 71-75.

14. Salmanov AG, Marievsky VF, Doan SI. Antibiotic resistance of clinical strains of Escherichia coli in surgical hospitals of Ukraine in 2009. Experimental and Clinical Medicine. 2010; 3(48): 137-143.

15. State Institution "Ukrainian Center of Monitoring and Disease Control of Health Ministry of Ukraine" 2011 [cited 2018 Jan 24]. Available from: http://www.moz.gov.ua

16. Kharchenko LA. AuRuM-Ukrainian experience of monitoring of antibiotic resistance. Health of Ukraine. 2011; 3: 1-3.

17. Nesterenko OM, Vorobyova TI. Clinical and microbiological substantiation of tactics of antimicrobial therapy of surgical sepsis. Pain, Anesthesia and Intensive Care. 2012; 1: 360-364.

18. Nestrenko OM. Degree of antibiotic resistance of pathogens as a dominant motivational factors of choice of antibiotic therapy tactics in sepsis. Kharkiv Surgical School. 2013; 3: 97-102.

19. Kreniov KYu. Microbiologic landscape dynamics in anesthesiology and intensive therapy department of Khmelnytskiy regional hospital in 2013-2016. Hospital Surgery. 2016; 1: 100-105.

20. Hrabák J, Študentová V, Adámková V. Report on a transborder spread of carbapenemase-producing bacteria by a patient injured during Euromaidan, Ukraine Mikrobiol Z. 2014; 76(3): 36-41.

21. Nesterenko AN, Khrypachenko IA. Local microbiological monitoring of hospital pathogens of surgical infection: substantiation of the initial empirical antibiotic therapy. Medicine of Urgent States. 2016; 4: 205. 